\title{
Monophasic Synovial Sarcoma of the Left Ventricle of the Heart: An Extremely Rare Case and Literature Review
}

\author{
Anindhita Muthmaina ${ }^{1}$, Ery Kus Dwianingsih ${ }^{2 *}$, Shinta Andi Sarasati ${ }^{2}$, Hendry Purnasidha Bagaswoto ${ }^{1}$, \\ Hasanah Mumpuni ${ }^{1} \mathbb{D}$ \\ ${ }^{1}$ Departement of Cardiology and Vascular Medicine, Faculty of Medicine, Public Health and Nursing, Universitas Gadjah Mada, \\ Dr. Sardjito General Hospital, Yogyakarta, Indonesia; ${ }^{2}$ Department of Anatomical Pathology, Faculty of Medicine, Public Health \\ and Nursing, Universitas Gadjah Mada, Dr. Sardjito General Hospital, Yogyakarta, Indonesia
}

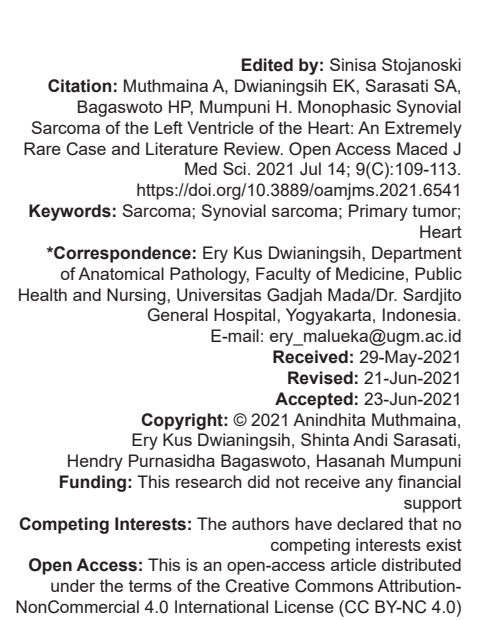

\begin{abstract}
BACKGROUND: Cardiac sarcomas account for $<25 \%$ of all cardiac tumors. Of these, angiosarcomas are the most frequent. Synovial sarcomas (SS) are exceedingly rare. We present a case of primary left ventricle (LV) SS, a form of sarcoma particularly rare in the heart.

CASE DESCRIPTION: A 19-year-old male was referred for further investigation of a LV tumor, presented with a 3-month history of exertional dyspnea and palpitations. He also experienced several syncopal episodes. The radiologic examination confirmed a mass in the LV, suspected for myxoma of the LV. Histopathologic examination revealed a malignant tumor with spindle cell components, suggesting leiomyosarcoma with differential diagnosis of monophasic SS. Immunohistochemistry demonstrated reactivity of the spindle cell component with the mesenchyma marker vimentin and BCL2 protein, while the smooth muscle marker, desmin, was negative, confirming the diagnosis of monophasic SS.

CONCLUSIONS: Monophasic SS in the heart is diagnostically challenging since it shares the broad list of differential diagnoses of spindle cell tumors. Immunostaining is helpful to differentiate those entities to obtain a definitive diagnosis and proper treatment.
\end{abstract}

\section{Introduction}

Primary cardiac tumors are very rare, and most of them are benign. Malignant primary cardiac tumor only represents $25 \%$ of all primary cardiac tumors, and most of them are sarcomas [1]. Undifferentiated sarcoma is the most common type of sarcoma in the heart, followed by angiosarcoma $(25 \%)$, leiomyosarcoma (25\%), and synovial sarcoma (SS) [2]. In another study, angiosarcoma was found as the most frequent sarcoma, followed by malignant fibrous histiocytoma, leiomyosarcoma, and SS. Cases with SS only account for $2 \%$ of the sarcomas in the heart [2], [3]. Primary cardiac sarcomas are predominantly located in the heart's right side, with the right to left side ratio of $2: 1$ [4]. In this case, we report the left ventricle's (LVs) primary cardiac SS, with a chief complaint of syncope. The diagnosis was confirmed by histopathological analysis and immunostaining.

\section{Case Description}

A 19-year-old male patient was suddenly unconscious when he was working 3 weeks prior to hospital admission. Palpitation or chest pain was not reported prior to unconsciousness event. Initially, the patient did not seek for medical help, however, a week later the symptom was repeated. He went to a private hospital, and congenital heart disease was suspected. An echocardiographic examination was performed and revealed a mass at the $L V$. He was referred to Dr. Sardjito General Hospital with the diagnosis of suspected LV Myxoma. Physical examination showed a 2/6 pan systolic murmur in the apex. Transthoracic and transoesophageal echocardiography examinations were performed, and showed two LV masses: one sized $2.6 \mathrm{~cm} \times 1.5 \mathrm{~cm}$ attached to the posterior mitral left, and another, sized $1.2 \mathrm{~cm} \times 2.1 \mathrm{~cm}$ with peduncle attached to the anterior mitral leaflet that obstructed the LV outflow tract (LVOT) (Figures 1 and 2). A Cardiac 


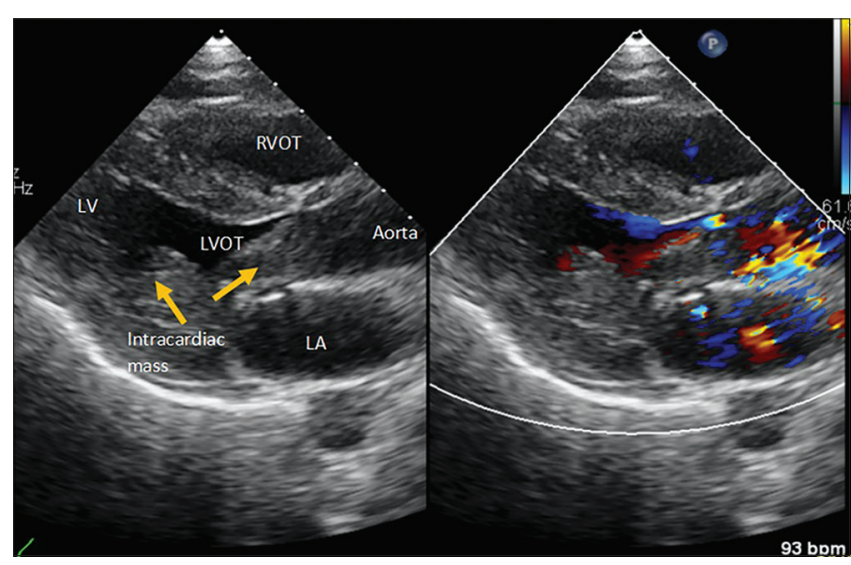

Figure 1: Transthoracic echocardiography showed two masses (yellow arrows) attached to mitral valves and obstructed LVOT. $R V O T=$ right ventricular outflow tract, $L V=$ Left ventricle, $L A=L$ eft atrium, $L V O T=$ Left ventricular outflow tract

Multi-Slice Computed Tomography was performed and showed a pedunculated mass in the LV, size $2.3 \mathrm{~cm} \times$ $2.3 \mathrm{~cm} \times 4.7 \mathrm{~cm}$ (Figure 3).

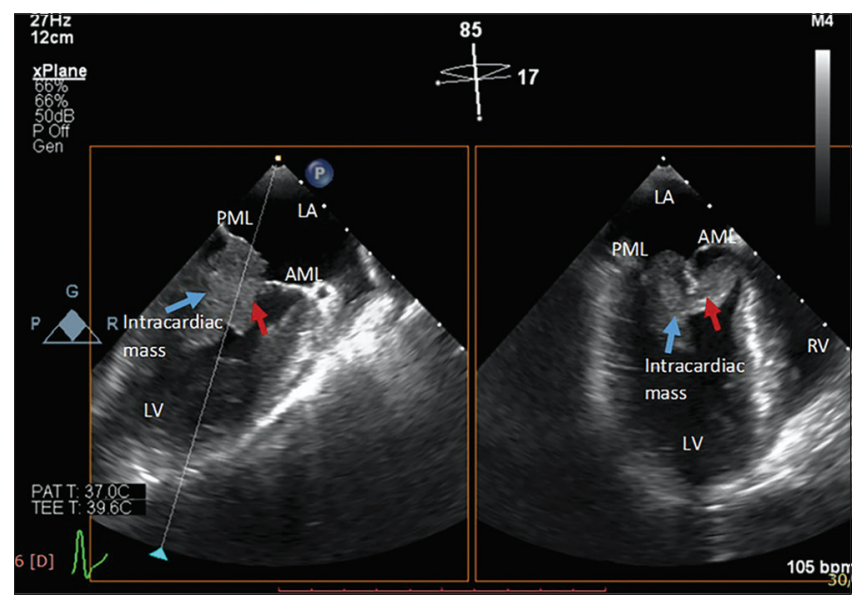

Figure 2: Transoesophageal echocardiography showed two masses that originated from $A M L$ with the size of $1.2 \mathrm{~cm} \times 2.1 \mathrm{~cm}$ (red arrow) and $P M L$ with size $2.6 \mathrm{~cm} \times 1.5 \mathrm{~cm}$ (blue arrow). $L A=L$ eft atrium, $L V=$ Left ventricle, $R V=$ Right ventricle, $P M L=$ Posterior mitral leaflet, $A M L$ = Anterior mitral leaflet

Enlarged lymph nodes or intrathoracic mass were not detected, and then open-heart surgery was performed. The procedure was started with cannulation of the aorta, inferior and superior cava veins. The cardiopulmonary bypass machine was started and cardioplegia administrated. The surgeons opened the right atrium and the interatrial septum to visualize the mitral valve and the tumor. A single encapsulated cardiac tumor with a size of $5 \mathrm{~cm} \times 2.5 \mathrm{~cm} \times 1.3 \mathrm{~cm}$ was found. The tumor was removed, and the mitral valve was replaced with a St. Jude mechanical valve size $29 \mathrm{~mm}$. The atria were closed and the patient was rewarmed. The procedure was completed without any complications.

The tumor mass was sent to the Anatomical Pathology department for a morphologic examination. The histopathology analysis revealed a mesenchymal tumor arranged in hypercellular fascicular architecture with a small intervening stroma, infiltrative to surrounding stroma. Hyalinization and myxoid changes were observed. Tumor

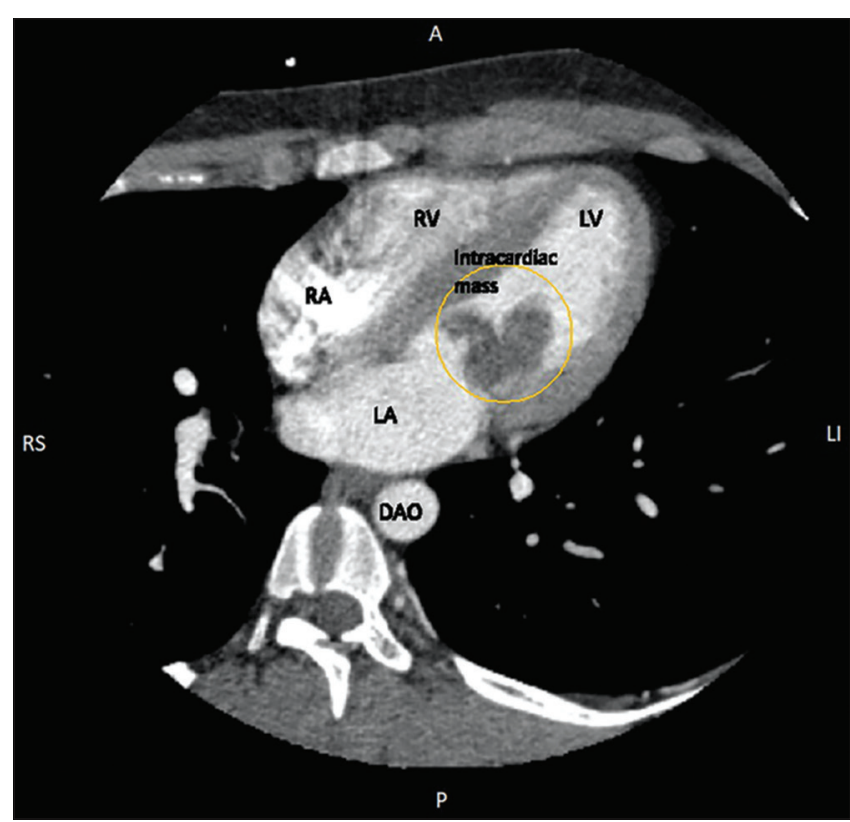

Figure 3: Cardiac CT showed a pedunculated mass in the LV with the size of $2.3 \mathrm{~cm} \times 2.3 \mathrm{~cm} \times 4.7 \mathrm{~cm}$ (yellow circle). $L A=$ Left atrium, $L V=L$ eft ventricle, $R A=$ Right atrium, $R V=$ Right ventricle, $D A O=$ Descending aorta, $R S=$ Right superior, $L I=$ Left inferior, $A=$ Anterior, $P=$ Posterior

cells were polymorphic with scant amphophilic cytoplasm, ovoid-to-spindled vesicular nuclei with evenly dispersed chromatin, and inconspicuous nucleoli. Glandular differentiation was not observed in the morphological features. A suspicion of leiomyosarcoma, with differential diagnosis of monophasic SS of the heart, was established. Immunostaining analysis using specific antibodies was performed to differentiate those entities. The results showed positive expression of BCL2 and negative expression of desmin, suggesting SS with a monophasic variant. Tumor proliferation was observed with Ki67 immunostaining and exhibited a $25 \%$ proliferation index (Figure 4). The diagnosis was then confirmed as monophasic SS. The

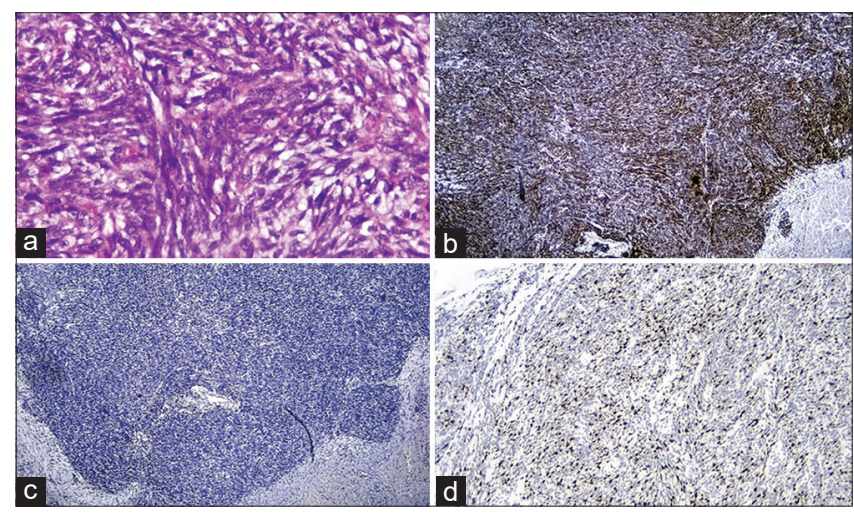

Figure 4: (a) showed Hematoxylin and Eosin staining, magnified 400 times, showing fascicular arrangement, consisting of the spindle, with some degree of mitosis, that supported the suspicion of leiomyosarcoma or monophasic synovial sarcoma. Immunostaining was performed to differentiate those entities. (b) showed immunostaining with BCL2 magnified 40 times, positively stained in tumor cells' cytoplasm. (c) showed Desmin immunostaining, magnified 40 times, showed a negative result. (d) showed Ki67 immunostaining, magnified 100 times, positively stained in nuclei $25 \%$ cell. The morphology and immunostaining result confirmed the diagnosis of monophasic synovial sarcoma 
patient was discharged 10 days later with good postoperative condition. The patient was screened for any other similar malignancy in various body parts by performing a bone survey and abdominal ultrasound. However, none were detected. As a treatment plan, he was scheduled for chemotherapy with Doxorubicin-Ifosfamide-Mesna regimen for six times at 28 days intervals. The post-chemo evaluation was performed and showed no residuals nor relapse. The patient gave his consent to submit his case for publication.

\section{Discussion}

The heart's primary SS is a rare tumor, accounting for only $2 \%$ of cardiac sarcomas, with the left atrium and pericardium as the predominant site [3].
Most SS of the heart is predominantly right-sided (ten cases), with seven tumors in the right atrium and three in the right ventricle. Predicted prognosis based on age is challenging to conclude because of the wide variation of age and few cases reported. Cardiac SS patients involving the left side of the heart are extremely rare; there are only three cases reported of primary SS of the LV [5], [6], [7].

A total of sixteen cases and the current case of cardiac SS are listed in Table 1. The average age was 38 years ranging from 17 to 66 years. At 19, the indexed case is much younger compared to the median age of previous cases. The clinical presentation is similar to the other tumors located in the heart. The symptoms are usually caused by a local obstruction or functional interference, which clinically can present as dyspnea, chest pain, congestive heart failure, and syncope [8]. The sarcoma may cause emboli to the cerebral vasa and present as a cerebrovascular accident [6], [9].

Table 1: Cases of synovial sarcoma of the heart, including the index case

\begin{tabular}{|c|c|c|c|c|c|c|c|c|}
\hline Reference & Case Age & Sex & Clinical feature & Site & Size/Gross & Diagnosis & Treatment & Follow-up \\
\hline Burke et al., 1992 [15] & 38 & & $\begin{array}{l}\text { Dyspnea, chest pain, } \\
\text { syncope }\end{array}$ & RV & & SS & & \\
\hline Burke et al., 1992 [15] & 38 & & $\begin{array}{l}\text { dyspnea, chest pain, } \\
\text { syncope }\end{array}$ & LA & & ss & & \\
\hline Boulter et al., 2009 [16] & 24 & $\mathrm{~F}$ & Dyspnea, palpitations & LA & $5.1 \mathrm{~cm}$ by $2.9 \mathrm{~cm}$ & MSS & $\begin{array}{l}\text { Partial excision, Adjuvant } \\
\text { chemotherapy with } \\
\text { adriamycin }\end{array}$ & $\begin{array}{l}\text { Doing well at her } \\
\text { 4-month follow-up }\end{array}$ \\
\hline Hussain et al., 2012 [17] & 28 & M & $\begin{array}{l}\text { facial oedema, distention } \\
\text { of neck veins and } \\
\text { systemic hypertension }\end{array}$ & RA & & MSS & $\begin{array}{l}\text { Surgical resection } \\
\text { followed by radiation } \\
\text { therapy }\end{array}$ & $\begin{array}{l}4 \text { months following } \\
\text { surgery, the patient } \\
\text { developed multiple } \\
\text { lung and neck nodules } \\
\text { metastasis }\end{array}$ \\
\hline Bittira et al., 2000 [9] & 47 & M & $\begin{array}{l}\text { transient right arm } \\
\text { weakness, right-sided } \\
\text { facial droop, and aphasia }\end{array}$ & RA & $3.9 \mathrm{~cm} \times 4.2 \mathrm{~cm}$ & BSS & $\begin{array}{l}\text { complete resection and } \\
\text { adriamycin chemotherapy }\end{array}$ & \\
\hline Sharma et al., 2015 [11] & 26 & $\mathrm{~F}$ & dyspnea and giddiness & LA & $7 \mathrm{~cm} \times 5 \mathrm{~cm}$ & BSS & $\begin{array}{l}\text { complete resection and } \\
\text { chemotherapy }\end{array}$ & $\begin{array}{l}\text { After } 1 \text { month patient } \\
\text { showed metastasis to } \\
D \quad 8 \text { and } L 2 \text { vertebral } \\
\text { bodies }\end{array}$ \\
\hline Hazelbag et al., 2004 [5] & 17 & M & $\begin{array}{l}\text { anorexia shortness of } \\
\text { breath }\end{array}$ & RV & $\begin{array}{l}8 \mathrm{~cm} \times 7 \mathrm{~cm} \times \\
6.5 \mathrm{~cm}\end{array}$ & MSS & $\begin{array}{l}\text { Resection and } \\
\text { chemotherapy }\end{array}$ & \\
\hline Okoro et al., 2017 [6] & 35 & M & Cardiomegaly, pneumonia & RA & $\begin{array}{l}15 \mathrm{~cm} \times 11 \mathrm{~cm} \\
\times 7 \mathrm{~cm}\end{array}$ & MSS & resection & \\
\hline Donsbeck et al. 1999 [2] & 34 & M & dyspnea & RA & & SS & & \\
\hline Hannachi et al., 2004 [1] & 45 & M & dyspnea, orthopnea & RA & $\begin{array}{l}7.0 \mathrm{~cm} \times 5.0 \mathrm{~cm} \\
\times 3.0 \mathrm{~cm}\end{array}$ & BSS & $\begin{array}{l}\text { Local excision and patch } \\
\text { reconstruction of the } \\
\text { atrial wall }\end{array}$ & Disease-free at 5 years \\
\hline Zhang et al., 2011 [18] & 36 & M & $\begin{array}{l}\text { shortness of breath, } \\
\text { dyspnea on exertion, } \\
\text { paroxysmal nocturnal } \\
\text { dyspnea, and intermittent } \\
\text { hemoptysis of 1-month } \\
\text { duration }\end{array}$ & $\begin{array}{l}\text { RA, } \\
\text { LA }\end{array}$ & $\begin{array}{l}2.5 \mathrm{~cm} \times 2.9 \mathrm{~cm} \\
\text { and the other, } \\
4.7 \mathrm{~cm} \times 2.9 \mathrm{~cm} \\
\times 3.6-3.8 \mathrm{~cm}\end{array}$ & MSS & Biopsy and chemotherapy & $\begin{array}{l}\text { Overall condition and } \\
\text { long-term outcome } \\
\text { remain guarded. } \\
\text { A recent follow-up } \\
\text { echocardiogram } \\
\text { revealed tumor regrowth } \\
\text { in the RA }\end{array}$ \\
\hline Maleki et al., 2017 [19] & 21 & $\mathrm{~F}$ & dyspnea and weakness & RA & $\begin{array}{l}7.5 \mathrm{~cm} \times 5.5 \mathrm{~cm} \\
\times 3.2 \mathrm{~cm}\end{array}$ & ss & excision & \\
\hline Okoro et al., 2017 [6] & 41 & $\mathrm{~F}$ & $\begin{array}{l}\text { Migraines with complaints } \\
\text { of sudden onset of left- } \\
\text { sided hemiplegia, facial } \\
\text { paralysis, and dysarthria. }\end{array}$ & LV & $1.7 \mathrm{~cm} \times 1.8 \mathrm{~cm}$ & BSS & $\begin{array}{l}\text { Excision and } \\
\text { chemotherapy }\end{array}$ & \\
\hline Braham et al., 2018 [20] & 63 & $\mathrm{~F}$ & $\begin{array}{l}\text { dyspnea NYHA III, } \\
\text { lipothymia and lower chest } \\
\text { pain that had started } 1 \\
\text { month earlier }\end{array}$ & RV & & ss & $\begin{array}{l}\text { Surgical and adjuvant } \\
\text { chemotherapy }\end{array}$ & $\begin{array}{l}\text { 8-year survival time } \\
\text { following surgical and } \\
\text { adjuvant chemotherapy }\end{array}$ \\
\hline Vinod et al., 2018 [21] & 66 & $\mathrm{~F}$ & $\begin{array}{l}\text { complaints of progressive } \\
\text { exertional dyspnea, } \\
\text { orthopnea, paroxysmal } \\
\text { nocturnal dyspnea (PND) } \\
\text { and exercise intolerance }\end{array}$ & LA & $4.1 \mathrm{~cm} \times 3.4 \mathrm{~cm}$ & BSS & $\begin{array}{l}\text { Surgical and } \\
\text { chemotherapy }\end{array}$ & \\
\hline Zhang et al., 2019 [22] & 52 & M & $\begin{array}{l}\text { thrombocytopenia, } \\
\text { bilateral lower extremity } \\
\text { oedema }\end{array}$ & MV & $5 \mathrm{~cm} \times 3.5 \mathrm{~cm}$ & BSS & $\begin{array}{l}\text { Surgical and } \\
\text { chemotherapy }\end{array}$ & $\begin{array}{l}\text { Patient died suddenly } 6 \\
\text { months later }\end{array}$ \\
\hline Our case & 19 & M & $\begin{array}{l}\text { 3-month history of } \\
\text { exertional dyspnea and } \\
\text { palpitations, several } \\
\text { syncopal episodes }\end{array}$ & LV & $\begin{array}{l}5 \mathrm{~cm} \times 2.5 \mathrm{~cm} \times \\
0.5-1.3 \mathrm{~cm}\end{array}$ & MSS & $\begin{array}{l}\text { Surgical and } \\
\text { chemotherapy }\end{array}$ & $\begin{array}{l}\text { Still receiving } \\
\text { chemotherapy protocol }\end{array}$ \\
\hline
\end{tabular}


In this case, the SS had originated from the LV and obstructed the LVOT; thus, it manifested as syncope in this patient.

The sarcoma can arise from any part of the heart, and when it originates from the valvular structure, it usually has pedunculated morphology [8]. In this case, at first, the pedunculated mass was suspected as myxoma, since it accounts for $50 \%$ of cardiac mass cases [10]. We concluded that the SS in the heart was a primary tumor since we did not find another tumor outside the heart. We also did not find any evidence of SS with metastasis, especially in the lungs, as the most common metastatic site. The average tumor size was $7 \mathrm{~cm}$ (range $0.5-7.5 \mathrm{~cm}$ ) in seventeen SS cases of the heart, with the largest at $15 \mathrm{~cm}$ and the smallest was $1 \mathrm{~cm}$. Histologically, SS may display biphasic patterns, with epithelial and spindle cell components, while spindle cell components characterize the monophasic variant [4], [8]. In our review, there were six cases with monophasic SS, six cases with biphasic SS, and five cases that did not elaborate in detail concerning their histologic variants. In monophasic SS cases, the diagnosis can be challenging since it is frequently confused with leiomyosarcoma, fibrosarcoma, hemangiopericytoma, or malignant nerve sheath tumor. To differentiate those entities, immunostaining is needed to confirm the diagnosis [4], [8]. The SS shows positive immunostaining of the spindle cells for BCL2 and epithelial cells for cytokeratin and epithelial membrane antigen. The SS in our case was of the monophasic variety positively stained with vimentin, BCL2 protein, and negatively stained desmin [2], [4]. In some cases, the difference can only be made using chromosomal translocation analysis, with the hallmark being the detection of $t(X ; 18)(p 11.2 ; q 11.2)$, which presents in $90 \%$ of cases [5].

Surgery has been the primary treatment of the SS cases since wide excision is required for a better outcome, followed by chemotherapy. The prognosis of $\mathrm{SS}$ is poor, with the most common causes of death as tumor recurrence and metastasis [8], [11]. Favorable factors for better survival are the young age when the diagnosis was made, the absence of chromosomal abnormalities, and the pericardium origin tumor. In contrast, older age at diagnosis contributes to poor prognosis. However, since the incidence of SS is rare, the prognostic factors are hard to ascertain [4], [12].

The primary cardiac tumor has a poor prognosis. A recent study by Yin et al. in 2020 showed that patients with primary cardiac tumors had a median survival of 7 months, but the survival can be improved with surgery and chemotherapy [12]. The surgical procedure is aimed to remove the tumor completely, and the radical excision has the lowest recurrence [13]. In SS, chemotherapy after the surgical procedure will improve survival since SS is relatively more chemosensitive than any other soft-tissue sarcoma. The combination of ifosfamide and doxorubicin showed a better outcome than high-dose ifosfamide alone. There are several novel therapies for SS that are still under investigation, such as tyrosine kinase targeted therapy, epigenetic modifiers, and immunotherapy, that showed some promising preclinical and early results [14].

\section{Conclusions}

Primary cardiac SS is rare, and SS originating from the LV is extremely rare. Classic histopathology of the $\mathrm{SS}$ is a biphasic variant, showing glandular differentiation. Monophasic SS is diagnostically challenging since it shares the broad list of differential diagnoses of spindle cell tumors and needs immunostaining or molecular analysis for definitive diagnosis. SS is more chemosensitive than other soft-tissue sarcomas. Ifosfamide and doxorubicin combination had a better outcome; recently, some novel therapies were developed to improve patient survival. This new development substantiates the importance of definitive diagnosis to differentiate SS from other softtissue sarcomas.

\section{Consent}

Written informed consent for publication of his detail was obtained from the patient. Institutional approval was not required to publish this case report.

\section{References}

1. Sassi SH, Zargouni N, Dakhlia MS, Mrad K, Cammoun M, Ben Romdhane K. Primary synovial sarcoma of the heart. A clinicopathologic study of one case and review of the literature. Pathologica. 2004;96(1):29-34.

PMid:15137596.

2. Donsbeck AV, Ranchere D, Coindre JM, Le Gall F, Cordier JF, Loire R. Primary cardiac sarcomas: An immunohistochemical and grading study with long-term follow-up of 24 cases. Histopathology. 1999;34(4):295-304. https://doi. org/10.1046/j.1365-2559.1999.00636.x

PMid: 10231396

3. Burke A. Primary malignant cardiac tumors. Semin Diagnostic Pathol. 2008;25:39-46

4. Varma T, Adegboyega P. Primary cardiac synovial sarcoma. Arch Pathol Lab Med. 2012;136(4):454-8.

PMid:22458908

5. Hazelbag HM, Szuhai K, Tanke HJ, Rosenberg C Hogendoorn PC. Primary synovial sarcoma of the heart: A cytogenetic and molecular genetic analysis combining RT-PCR and COBRA-FISH of a case with a complex karyotype. Mod Pathol. 2004;17(11):1434-9. https://doi.org/10.1038/ 
modpathol.3800200

PMid:15494710

6. Okoro KU, Roby MD, Sane DC, Budin RE. Infiltrating cardiac synovial sarcoma presenting as acute cerebrovascular accident. Case Rep Med. 2017;2017:8539606. https://doi. org/10.1155/2017/8539606

PMid:29333163

7. Prifti E, Veshti A, Ikonomi M, Demiraj A. Primary cardiac synovial sarcoma originating from the mitral valve causing left ventricular outflow tract obstruction. World J Pediatr Congenit Heart Surg. 2015;6(4):650-3. https://doi.org/10.1177/2150135115579109 PMid:26467881

8. Zhao Q, Geha AS, Devries SR, Tshibaka C, Wu S, Lavi N, et al. Biatrial primary synovial sarcoma of the heart. Am Soc Echocardiogr. 2007;197.e1-4. https://doi.org/10.1016/j. echo.2006.08.035

9. Bittira B, Tsang J, Huynh T, Morin JF, Huttner I. Primary right atrial synovial sarcoma manifesting as transient ischemic attacks. Ann Thorac Cardiovasc Surg. 2000;69(6):1949-51. https://doi.org/10.1016/s0003-4975(00)01283-2 PMid:10892961

10. Grubb KJ, Jevremovic V, Chedrawy EG. Mitral valve myxoma presenting with transient ischemic attack: A case report and review of the literature. J Med Case Rep. 2018;12(1):363. https://doi.org/10.1186/s13256-018-1920-8 PMid:30526679

11. Sharma A, Dixit S, Sharma M, Sharma N, Sharma O. Primary synovial cell sarcoma of the heart: A rare case. Hear Views. 2015;16(2):62-4. https://doi.org/10.4103/1995-705x.159223 PMid:26240736

12. Yin $\mathrm{K}$, Luo R, Wei $\mathrm{Y}$, Wang $\mathrm{F}$, Zhang $\mathrm{Y}$, Karlson $\mathrm{KJ}$, et al. Survival outcomes in patients with primary cardiac sarcoma in the United States. J Thorac Cardiovasc Surg. 2020;162(1):107-15.e2. PMid:32111430

13. Grimer R, Judson I, Peake D, Seddon B. Guidelines for the management of soft tissue sarcomas. Sarcoma. 2010;2010:506182. https://doi.org/10.1155/2010/506182 PMid:20634933

14. Desar IM, Fleuren ED, van der Graaf WT. Systemic treatment for adults with synovial sarcoma. Curr Treat Options Oncol. 2018;19(2):1-7. https://doi.org/10.1007/s11864-018-0525-1 PMid:29516254

15. Burke AP, Cowan D, Virmani R. Primary sarcomas of the heart Cancer. 1992;69(2):387-95.

PMid:1728367

16. Boulter DJ, Rosado-de-Christenson ML, Stevens R, Suster S. Primary synovial sarcoma of the lung. Radiol Case Reports. 2009;2(4):82. https://doi.org/10.2484/rcr.v2i4.82

17. Hussain $\mathrm{S}$, Khan AA, Khan Q. Synovial sarcoma of the heart. J Coll Physicians Surg Pakistan. 2012;22(11):723-5. PMid:23146855

18. Zhang $\mathrm{L}$, Qian J, Li Z, Jing $\mathrm{H}$. Primary synovial sarcoma of the heart. Cardiol J. 2011;18(2):128-33.

19. Maleki MH, Makouei MA, Hatami F, Noghabi RZ. Primary cardiac synovial sarcoma: A case report. J Tehran Univ Hear Cent. 2017;12(1):32-4. PMid:28469690

20. Braham W, Pisani A, Poitier B, Sannier A. Primary cardiac synovial sarcoma: An asymptomatic patient 8 years after the primary surgery. Interact Cardiovasc Thorac Surg. 2018;27(3):471-3. https://doi.org/10.1093/icvts/ivy108 PMid:29617796

21. Vinod P, Jabri A, Hegde V, Lahorra J, Cutler D. Functional mitra stenosis: Imposture of primary cardiac intimal sarcoma. Cardiol Res. 2018;9(5):307-13. https://doi.org/10.14740/cr748w PMid:30344829

22. Zhang G, Gao Q, Chen S, Chen Y. Primary cardiac synovial sarcoma that was continuous with the mitral valve caused severe thrombocytopenia: A case report. J Cardiothorac Surg. 2019;14(1):1-6. https://doi.org/10.1186/s13019-019-0852-8 